\title{
Seroprevalence of Neospora caninum-specific antibodies in German breeding bitches
}

\author{
Rodolfo Villagra-Blanco ${ }^{1,2^{*}}$, Lora Angelova ${ }^{3}$, Theresa Conze ${ }^{1}$, Gereon Schares ${ }^{4}$, Andrea Bärwald ${ }^{4}$, Anja Taubert ${ }^{2}$, \\ Carlos Hermosilla ${ }^{2}$ and Axel Wehrend ${ }^{1}$
}

\begin{abstract}
Background: Neospora caninum is an intracellular obligate apicomplexan parasite responsible for multisystemic lesions in dogs. Being definitive hosts and reservoirs, dogs excrete environmentally resistant oocysts. Breeding bitches represent a susceptible dog group and infected bitches may spread this parasite through transplacental transmission.
\end{abstract}

Results: A total of 218 serum samples of German breeding bitches were collected to determine the presence of $\mathrm{N}$. caninum. Antibodies were detected in 16 (7.33\%) bitches using a commercial indirect enzyme-linked immunosorbent assay (ELISA). Immunoblotting analysis confirmed all seropositive samples detected by ELISA, proving that the animals were infected with $N$. caninum. The owners were interviewed regarding breed, age, environment, type, vaccine status, feeding habits and the presence of reproductive disorders. Seropositive animals were between the ages of two to seven years; three of them were kept in kennels while the others were household dogs, one of which was additionally a hunting dog. Owners of four seropositive bitches reported one gestation, while multiple pregnancies had been recorded for the other twelve bitches. Fourteen bitches were regularly vaccinated and six were fed with fresh raw meat.

Conclusions: Although the results confirmed a low incidence of N. caninum seropositive German breeding bitches, further epidemiological and surveillance studies are required to complement our findings regarding the current situation of neosporosis in this specific canine population of Germany.

Keywords: Neospora caninum, Reproduction, Breeding bitches, Germany

\section{Background}

Neospora caninum is an apicomplexan obligate intracellular parasite that causes multisystemic lesions in dogs [1-5]. Dogs can act as definitive as well as intermediate hosts during $N$. caninum infections [6, 7]. Canine neosporosis is characterised by neuromuscular symptoms, such as ataxia, ascending paralysis, and other general nervous clinical signs [8]. Other manifestations include myocardial, pulmonary, dermatological, as well as reproductive disorders [3, 9-12]. Neospora caninum infections can occur through horizontal and vertical transmission

\footnotetext{
* Correspondence: Rodolfo.A.Villagra-Blanco@vetmed.uni-giessen.de ${ }^{1}$ Clinic for Obstetrics, Gynaecology and Andrology of Large and Small Animals with Veterinary Ambulance, Faculty of Veterinary Medicine, Justus Liebig University Giessen, 35392 Giessen, Germany

${ }^{2}$ Institute of Parasitology, Faculty of Veterinary Medicine, Justus Liebig University Giessen, 35392 Giessen, Germany

Full list of author information is available at the end of the article
}

of the parasite, i.e. a foetus may become infected transplacentally. In addition, dogs can be postnatally infected through the oral uptake of cysts from infected tissue material or sporulated $N$. caninum oocysts in contaminated food or water sources $[11,13,14]$. Oocysts are greatly significant in the spread and maintenance of this abortive agent, which is known to be highly tenacious $[6,7,15]$.

Female dogs that have given birth to pups congenitally infected with $N$. caninum do not present any clinical signs [13]. Nevertheless, transmission of the protozoan to offspring in succeeding generations can occur $[3,16]$.

There are many diagnostic methods used to detect this parasite, such as histology, immunochemistry, serology, and conventional and real-time PCR $[5,17,18]$. Despite the fact that clinical canine neosporosis is rare, there are many reports on the seroprevalence of $N$. caninum in domestic and wild canines $[10-13,15]$. Even among different canine populations with diverse roles and environments, distinct 
seroprevalences have been reported in stray [19], farm-rural [20-24], kennel [20] and urban dogs [21, 23-25].

European studies revealed differences in $N$. caninum seroprevalence; three of them were kept in kennels while the others were household dogs, one of which was additionally a hunting dog of various canine populations, presenting with $15.3 \%$ seroprevalence in Denmark [9], 3.6\% in Austria [26], 2.6-19.2\% in Czech Republic [27], 17.2\% in Serbia [28], $32.7 \%$ in Romania [29], $16.36 \%$ or $21.7 \%$ in Poland $[25,30], 10.9 \%$ in Italy [31], $12.2 \%$ in Spain [32],0.5\% in Sweden [33] and 4\% or 13\% in Germany [34].

The aim of the present study was to determine the presence of $N$. caninum antibodies in German breeding female dogs and describe the characteristics of seropositive animals that may be correlated with this parasite and their potential involvement in reproductive disease.

\section{Methods}

\section{Analysed population and sample size}

Female dogs that showed optimal health parameters were presented for routine progesterone concentration measurements for ovulation determination at the Clinic for Obstetrics, Gynaecology and Andrology of the Justus Liebig University (JLU) Giessen, Germany. All bitches participating in this study were previously subjected to a clinical examination. A total of 218 samples were collected from March 2016 to June 2017 to determine the presence of $N$. caninum and the correlation between a current infection and reproductive disorders. Owners of seropositive animals were contacted and requested to complete a questionnaire that asked about breed, age, environment (indoors or outdoors, urban or rural), type of dog (farm, hunting, kennel, police, rescue, household/ pet dogs), vaccination status (e.g. vaccinated against distemper virus, canine hepatitis virus, canine parvovirus, parainfluenza virus, Leptospira spp. and rabies), feeding habits, and reproductive disorders.

\section{Sample collection and additional information}

Blood was collected by puncture of the cephalic vein. Then, the samples were transported at $5-10{ }^{\circ} \mathrm{C}$. In the laboratory, samples were centrifuged for $5 \mathrm{~min}$ at $10000 \times g$, and then sera were separated and frozen at -20 ${ }^{\circ} \mathrm{C}$ until further analysis.

\section{Enzyme-linked immunosorbent assay (ELISA)}

The IDScreen ${ }^{\circ}$ Neospora caninum Indirect Multi-species ELISA from IDVet ${ }^{\circ}$ (Montpellier, France) was used for the detection of $N$. caninum-specific antibodies in canine serum samples. The same assay was employed in the studies by Sharma et al. [19], and Enăchescu et al. [35]. Sera were analysed, according to the ELISAmanufacturer's instructions. For validation, positive control optical density (OD) averages and the difference between positive and negative control OD averages were evaluated. According to OD data of different serum samples, serum positive percentages $(\mathrm{S} / \mathrm{P})$ were calculated with respect to the average of the positive control sera using the following formula: $\mathrm{S} / \mathrm{P}=$ (sample $\mathrm{OD} \times$ 100) / (average OD of positive control). As recommended by the ELISA-manufacturer, samples that yielded S/P percentages of less than $40 \%$ were classified negative, samples with $\mathrm{S} / \mathrm{P}$ values between $40-50 \%$ were weakly positive, and those with $\mathrm{S} / \mathrm{P}$ values higher than $50 \%$ were assumed positive for $N$. caninum infection. The seropositive samples detected by ELISA and 10\% of the remaining negative samples were further validated by immunoblotting assays.

\section{Immunoblot assays}

Two immunoblot assays were performed: one immunoblot was based on total tachyzoite antigen ( $\mathrm{NC}-1$ strain of $N$. caninum; Dubey et al. [36] cultivated in MARC145 cells), while the second immunoblot relied on p38 tachyzoite antigen (NcSRS2) application after affinity purification, as previously described [37].

Total tachyzoite antigen immunoblot was performed as described previously [38] using $8 \times 10^{7}$ tachyzoite pellets of N. caninum or purified NcSRS2 (p38, $0.05 \mu \mathrm{g}$ per SDS-PAGE protocol) [37, 39]. Antigens were incubated in non-reducing sample buffer $[2 \%(\mathrm{w} / \mathrm{v})$ SDS, $10 \%(\mathrm{v} / \mathrm{v})$ glycerol, $62 \mathrm{mM}$ Tris- $\mathrm{HCl}, \mathrm{pH}$ 6.8] for $1 \mathrm{~min}$ at $94^{\circ} \mathrm{C}$, separated on $12 \%$ SDS polyacrylamide minigels $(60 \times 70 \times 1 \mathrm{~mm})$, and transferred to PVDF membranes (Immobilon-P, Merck Chemicals GmbH, Darmstadt, Germany). After the transfer, membranes were blocked in PBS-TG consisting of PBS with $0.05 \%$ (v/v) Tween 20 (Sigma-Aldrich, Taufkirchen, Germany) and 2\% (v/v) liquid fish gelatin (Serva, Heidelberg, Germany), cut into 50 strips, and examined as described below. To detect antibodies against $N$. caninum tachyzoite antigens, western blot membrane strips were incubated as previously described [38]. Dog sera were diluted 1:100 in PBS-TG, and then immunoreactions were detected using a peroxidase anti-dog IgG conjugate (Dianova, Hamburg, Germany) diluted 1:1000 in PBS-TG. Sera of naturally $N$. caninum-infected and non-infected dogs [40] were used as positive and negative control, respectively. In the case of total antigen detection, reactivity of the sera with non-reduced immunodominant $N$. caninum tachyzoite antigens (NC-IDA) of 17-19, 29, 30, 33, and $37 \mathrm{kDa} \mathrm{Mr}$ was examined. For purified NcSRS2, reactivity at 37-39 $\mathrm{kDa}$ was analysed [37].

\section{Results}

Out of 218 analysed samples, 16 (7.33\%) were positive for $N$. caninum-specific antibodies as determined by ELISA and reported S/P values higher than 50\% (Table 1). 
Table 1 Distribution of seronegative and seropositive sera of $\mathrm{N}$. caninum according to the serum positive percentage (S/P) values determined with ELISA

\begin{tabular}{ll}
\hline Positivity percentage (SP) & Neospora caninum (\%) \\
\hline$\leq 30$ (negative serorreactors) & $202(92.6)$ \\
$31-50$ (low serorreactors) & $0(0)$ \\
$51-70$ (high positive serorreactors) & $1(0.6)$ \\
$\geq 71$ (very high positive serorreactors) & $15(6.8)$ \\
Total & $218(100.0)$ \\
\hline
\end{tabular}

Immunoblot-based analyses confirmed seropositivity of all samples detected positive by ELISA (Fig. 1) and the 20 representative samples found negative by ELISA (10\%).

Characteristics of the seropositive bitches are summarised in Table 2. The positive bitches were between two and seven years old, three (18.8\%) were kept in kennels and the remaining were household animals (75\%), including one (6.2\%) that was also used for hunting. During sampling, four (25\%) positive female dogs had been pregnant once, while the other 12 (75\%) had had more than one birth as reported by the owners. Six (37.5\%) seropositive individuals were fed with fresh raw meat not treated by cooking. Finally, 14 (87.5\%) of the 16 seropositive bitches had a full vaccination program recorded.

\section{Discussion}

The present study confirmed the presence of $N$. caninum antibodies in German breeding female dogs, which represent a susceptible $N$. caninum-infection dog group. Infected bitches may spread this parasite through transplacental transmission during successive pregnancies [41-43]. Immunoblot assays were used as a validation method for ELISA-positive and some ELISA-negative animals with the main purpose of avoiding false positive serological results and verifying the presence or absence of specific antibodies against $N$. caninum $[25,44]$.

The clinical and pathological isolation of $N$. caninum in an 11-week-old German puppy was previously reported [40]. Moreover, N. caninum faecal oocysts were found and cysts of this parasite were identified in German dogs [45, 46]. Previously, serological analyses of three German Doberman puppies from an infected bitch demonstrated the vertical transmission of $N$. caninum [42]. The low number of serologically positive dogs in this study (7.33\%) is in agreement with previous seroprevalence obtained for German dogs with (13\%) and without (4\%) clinical signs of neosporosis [34] and in dogs from the German Federal State of Rhineland-Palatinate (4.45\%) [47]. However, it should be noted that the novelty of this study relies on the low seroprevalence determined in canine breeding populations in Germany, specifically in the reproductive bitches population for which an $N$. caninum seroprevalence has not yet been described in the literature.

Transplacental transmission in dogs has been reported for experimental infections [48]; however, natural-neonatal canine neosporosis is rare and findings are variable, as not all litter puppies become seropositive [3]. Thus, frequent

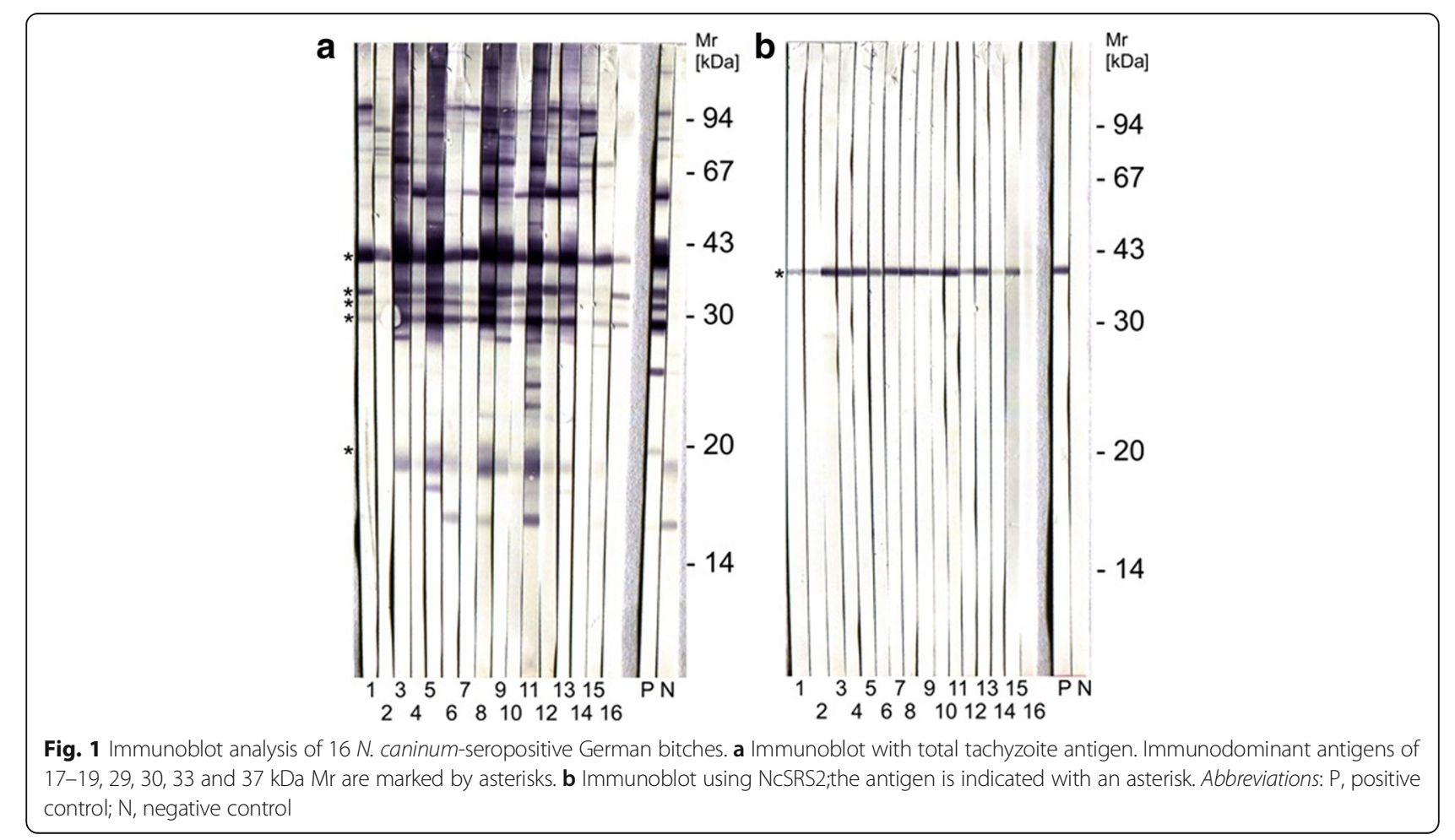


Table 2 Characteristics of $N$. caninum seropositive breeding bitches

\begin{tabular}{|c|c|c|c|c|c|c|}
\hline Animal & Breed & Age & Environment & Vaccination status & Feeding & Previous births \\
\hline 1 & Rhodesian ridgeback & 2 & Household & DHPPi+LR & Raw meat & 1 \\
\hline 2 & Shepherd dog & 6 & Household and kennel & $D H P P i+L R$ & Dry food and raw meat & $>1$ \\
\hline 3 & Giant schnauzer & 6 & Household & $D H P P i+L R$ & Raw meat & $>1$ \\
\hline 4 & Norwich terrier & 7 & Household & $D H P P i+L R$ & Dry and wet food & $>1$ \\
\hline 5 & Rhodesian ridgeback & 5 & Household & $D H P P i+L R$ & Raw meat & $>1$ \\
\hline 6 & German shepherd & 4 & Household & $D H P P i+L R$ & na & $>1$ \\
\hline 7 & Boston terrier & 4 & Household & $D H P P i+L R$ & Dry food & $>1$ \\
\hline 8 & English bulldog & - & Household & $D H P P i+L R$ & Dry food & $>1$ \\
\hline 9 & Giant schnauzer & 6 & Household & $D H P P i+L R$ & Raw meat & $>1$ \\
\hline 10 & Bernese mountain & 6 & Kennel & na & Dry food and raw meat & $>1$ \\
\hline 11 & English bulldog & - & Household & $D H P P i+L R$ & Dry food & $>1$ \\
\hline 12 & Bulldog & 5 & Household & $D H P P i+L R$ & Dry food & $>1$ \\
\hline 13 & Greater Swiss Mountain dog & 4 & Household & $D H P P i+L R$ & Dry food & $>1$ \\
\hline 14 & Rottweiler & 7 & Kennel & na & na & 1 \\
\hline 15 & Unknown & 4 & Household & $D H P P i+L R$ & Dry food & 1 \\
\hline 16 & Austrian black and tan hound & 2 & Household and hunting & $D H P P i+L R$ & Dry food & 1 \\
\hline
\end{tabular}

Abbreviations: na no answer, DHPPi + LR vaccination against distemper virus, canine hepatitis virus, canine parvovirus, parainfluenza virus, Leptospira spp. and rabies

canine transplacental transmission is unlikely to occur in the absence of horizontal infection [3, 49], highlighting the importance of investigating additional canine horizontal infection routes of $N$. caninum in seropositive breeding bitches $[3,50]$. All infection routes should be considered during the reproductive cycle of subclinical Neospora-infected bitches, especially considering that no drugs are known to prevent transplacental transmission [49]. Therefore, we also consulted with the owners of seropositive animals regarding risk factors of canine neosporosis identified in previous studies, such as breed [31], age [50], environment [51], type [20], vaccine status [52], and feeding habits [53].

Most of the individuals analysed were household, breeding female dogs. Several studies have demonstrated that European farm dogs have higher $N$. caninum seroprevalences than kennel, rescue, household, or urban dogs [20, $21,54]$. Seroprevalence was especially high in farm dogs that were kept with highly specialised dairy herds [22] or even with small ruminant flocks [23]; however, most of the studies mainly focused on this type of canine population, with only a few investigating household breeding dogs [3].

In the present study, four of the female dogs studied were found to have received raw meat as part of their diet. Horizontal transmission of $N$. caninum occurs through the intake of tissue cysts $[55,56]$. Infection, as evidenced by shedding oocysts, was demonstrated in dogs after experimentally feeding them infected meat from goat and sheep [57].

Moreover, one positive household bitch was used for hunting proposes. Hunting dogs have an increased risk of being $N$. caninum-seropositive [24]. Possible contact with eviscerated infected wild animal carcasses (e.g. deer) might represent a potential source of infection [15, $29,47]$. In contrast with this observation, however, a serological study [9] found no statistical significance between seroprevalence of hunting and non-hunting dogs.

The vaccination status of the animals was also recorded to assure proper health status. In the present study, 14 out of 16 seropositive bitches were vaccinated. These data are in contrast with previous observations, in which vaccinated dogs had significantly lower seroprevalence compared with non-vaccinated canines [52]. The level of care provided by the dog owners regarding vaccination and diet were not correlated to $N$. caninum seropositivity.

Little is known about the clinical and economic consequences of canine neosporosis on the reproductive performance of breeding bitches and their progeny; therefore, further long-term studies are necessary to better understand the impact of neosporosis on breeding dog populations.

\section{Conclusions}

We concluded that $N$. caninum infections exist in German breeding bitches at a very low prevalence. Nonetheless, further epidemiological studies are required to obtain more information regarding the seroprevalence of other German canine populations.

\section{Acknowledgements}

We would like to thank Julia Blad-Stahl (Clinic for Obstetrics, Gynaecology and Andrology, JLU Giessen, Germany) and Christine Henrich (Institute of 
Parasitology, JLU Giessen, Germany) for their invaluable technical assistance. We also acknowledge and thank the owners of the dogs that participated in this research.

\section{Funding}

This work was funded by the Ministerio de Ciencia, Tecnología y Telecomunicaciones (MICITT-Costa Rica) through the PINN program (PND-026-15-2) awarded to the PhD candidate RVB of the JLU Giessen, Germany.

\section{Availability of data and materials}

All data generated or analysed during this study are included in this published article.

\section{Authors' contributions}

TC contributed in sample collection and surveys. RVB and LA performed ELISA analysis. GS and AB conducted immunoblot analysis. RVB, LA, TC, GS, AW, AT and $\mathrm{CH}$ cooperated in research design, data analysis, and manuscript review. All authors read and approved the final manuscript.

\section{Ethics approval and consent to participate}

Not applicable.

\section{Consent for publication}

Not applicable.

\section{Competing interests}

The authors declare that they have no competing interests.

\section{Publisher's Note}

Springer Nature remains neutral with regard to jurisdictional claims in published maps and institutional affiliations.

\section{Author details}

${ }^{1}$ Clinic for Obstetrics, Gynaecology and Andrology of Large and Small Animals with Veterinary Ambulance, Faculty of Veterinary Medicine, Justus Liebig University Giessen, 35392 Giessen, Germany. ${ }^{2}$ Institute of Parasitology, Faculty of Veterinary Medicine, Justus Liebig University Giessen, 35392 Giessen, Germany. ${ }^{3}$ Veterinarian Health Center Wiesbaden-Bierstadt, 65191 Wiesbaden, Germany. ${ }^{4}$ Friedrich-Loeffler-Institut, Federal Research Institute for Animal Health, Institute of Epidemiology, 17493 Greifswald-Insel Riems, Germany.

Received: 12 October 2017 Accepted: 29 January 2018

Published online: 17 February 2018

\section{References}

1. Dubey JP, Metzger FL, Hattel AL, Lindsay DS, Fritz DL. Canine cutaneous neosporosis: clinical improvement with clindamycin. Vet Dermatol. 1995;6: 37-43.

2. Barber JS, Trees AJ. Clinical aspects of 27 cases of neosporosis in dogs. Vet Rec. 1996;139:439-43.

3. Barber JS, Trees AJ. Naturally occurring vertical transmission of Neospora caninum in dogs. Int J Parasitol. 1998;28(1):57-64.

4. Garosi L, Dawson A, Couturier J, Matiasek L, de Stefani A, Davies E, et al. Necrotizing cerebellitis and cerebellar atrophy caused by Neospora caninum infection: magnetic resonance imaging and clinico-pathologic findings in seven dogs. J Vet Intern Med. 2010:24:571-8.

5. Legnani S, Pantchev N, Forlani A, Zini E, Schares G, Balzer J, et al. Emergence of cutaneous neosporosis in a dog receiving immunosuppressive therapy: molecular identification and management. Vet Dermatol. 2016;27(1):49-e14.

6. Dubey JP. Neosporosis in cattle. J Parasitol. 2003a;89:42-56.

7. Dubey JP. Review of Neospora caninum and neosporosis in animals. Korean J Parasitol. 2003b:41:1-16.

8. Lindsay DS, Dubey JP. Canine neosporosis. J Vet Parasitol. 2000;14:1-11.

9. Rasmussen K, Jensen AL. Some epidemiologic features of canine neosporosis in Denmark. Vet Parasitol. 1996;62:345-9.

10. Lindsay DS, Dubey JP, Duncan RB. Confirmation that the dog is a definitive host for Neospora caninum. Vet Parasitol. 1999;82(4):327-33.
11. Dubey JP, Schares G, Ortega-Mora LM. Epidemiology and control of neosporosis and Neospora caninum. Clin Microbiol Rev. 2007a;20:323-67.

12. Dubey JP, Jenkins MC, Rajendran C, Miska K, Ferreira LR, Martins J, et al. Gray wolf (Canis lupus) is a natural definitive host for Neospora caninum. Vet Parasitol. 2011;181:382-7.

13. Dubey JP, Vianna MCB, Kwok OCH, Hill DE, Miska KB, Tuo W, et al. Neosporosis in Beagle dogs: clinical signs, diagnosis, treatment, isolation and genetic characterization of Neospora caninum. Vet Parasitol. 2007b;149: 158-66.

14. Cavalcante GT, Monteiro RM, Soares RM, Nishi SM, Alves Neto AF, Esmerini Pde $\mathrm{O}$, et al. Shedding of Neospora caninum oocysts by dogs fed different tissues from naturally infected cattle. Vet Parasitol. 2011;179:220-3.

15. Gondim LF, McAllister MM, Mateus-Pinilla NE, Pitt WC, Mech LD, Nelson ME. Transmission of Neospora caninum between wild and domestic animals. J Parasitol. 2004:90(6):1361-5.

16. Crookshanks JL, Taylor SM, Haines DM, Shelton GD. Treatment of canine pediatric Neospora caninum myositis following immunohistochemical identification of tachyzoites in muscle biopsies. Can Vet J. 2007;48:506-8.

17. Dubey JP, Schares G. Diagnosis of bovine neosporosis. Vet Parasitol. 2006; 140:1-34.

18. Cavalcante GT, Soares RM, Nishi SM, Hagen SCF, Vannucchi Cl, Maiorka PC et al. Experimental infection with Neospora caninum in pregnant bitches. Rev Bras Parasitol Vet. 2012;21(3):232-6.

19. Sharma R, Kimmitt T, Tiwari K, Chikweto A, Thomas D, Lanza Perea M, et al. Serological evidence of antibodies to Neospora caninum in stray and owned Grenadian dogs. Trop Biomed. 2015;32:286-90.

20. Paradies P, Capelli G, Testini G, Cantacessi C, Trees AJ, Otranto D. Risk factors for canine neosporosis in farm and kennel dogs in southern Italy. Vet Parasitol. 2007;145:240-4

21. Ferroglio E, Pasino M, Ronco F, Bena A, Trisciuoglio A. Seroprevalence of antibodies to Neospora caninum in urban and rural dogs in north-west Italy. Zoonoses Public Health. 2007:54:135-9.

22. Palavicini P, Romero JJ, Dolz G, Jiménez AE, Hill DE, Dubey JP. Fecal and serological survey of Neospora caninum in farm dogs in Costa Rica. Vet Parasitol. 2007;149:265-70.

23. Antony A, Williamson NB. Prevalence of antibodies to Neosporo caninum in dogs of rural or urban origin in central New Zealand. NZ Vet J. 2003:51(5):232-7.

24. Nogueira Cl, Mesquita LP, Abreu CC, Nakagaki KY, Seixas JN, Bezerra PS, et al. Risk factors associated with seroprevalence of Neospora caninum in dogs from urban and rural areas of milk and coffee production in Minas Gerais state, Brazil. Epidemiol Infect. 2013;141(11):2286-93.

25. Goździk K, Wrzesien R, Wielgosz-Ostolska A, Bien J, Kozak-Ljunggren M, Cabaj W. Prevalence of antibodies against Neospora caninum in dogs from urban areas in Central Poland. Parasitol Res. 2011;108:991-6.

26. Wanha K, Edelhofer R, Gabler-Eduardo C, Prosl H. Prevalence of antibodies against Neospora caninum and Toxoplasma gondii in dogs and foxes in Austria. Vet Parasitol. 2005;128:189-93.

27. Vaclavek P, Sedlak K, Hurkova L, Vodrazka P, Sebesta R, Koudela B. Serological survey of Neospora caninum in dogs in the Czech Republic and a long-term study of dynamics of antibodies. Vet Parasitol. 2007:143:35-41.

28. Kuruca L, Spasojević-Kosić L, Simin S, Savović M, Lauš S, Lalošević V. Neospora caninum antibodies in dairy cows and domestic dogs from Vojvodina. Serbia. Parasite. 2013;20:40.

29. Gavrea R, Mircean V, Pastiu A, Cozma V. Epidemiological survey of Neospora caninum infection in dogs from Romania. Vet Parasitol. 2012;188(3-4):382-5.

30. Płoneczka K, Mazurkiewicz M. Seroprevalence of Neospora caninum in dogs in southwestern Poland. Vet Parasitol. 2008;153:168-71.

31. Capelli G, Nardelli S, di Regalbono AF, Scala A, Pietrobelli M. Seroepidemiological survey of Neospora caninum infection in dogs in northeastern Italy. Vet Parasitol. 2004;123(3-4):143-8.

32. Ortuño A, Castella J, Almeria S. Seroprevalence of antibodies to Neospora caninum in dogs from Spain. J Parasitol. 2002;88:1263-6.

33. Björkman C, Lunden A, Uggla A. Prevalence of antibodies to Neospora caninum and Toxoplasma gondii in Swedish dogs. Acta Vet Scand. 1994;35:445-7.

34. Klein BU, Müller E. Seroprevalence of antibodies to Neospora caninum in dogs with and without clinical suspicion for neosporosis in Germany. Der praktische Tierarzt. 2001:82:437-40, (in German)

35. Enăchescu V, loniță M, Mitrea IL. Preliminary data in comparative serodiagnostic of Neospora caninum in dogs. Scientific Works. C Series. Vet Med. 2012;58(4):128-35. 
36. Dubey JP, Hattel AL, Lindsay DS, Topper MJ. Neonatal Neospora caninum infection in dogs: isolation of the causative agent and experimental transmission. J Am Vet Med Assoc. 1988;193:1259-63.

37. Schares G, Rauser M, Söndgen P, Rehberg P, Bärwald A, Dubey JP, et al. Use of purified tachyzoite surface antigen p38 in an ELISA to diagnose bovine neosporosis. Int J Parasitol. 2000;30:1123-30.

38. Schares G, Peters M, Wurm R, Bärwald A, Conraths FJ. The efficiency of vertical transmission of Neospora caninum in dairy cattle analysed by serological techniques. Vet Parasitol. 1998;80:87-98.

39. Azevedo SS, Pena HF, Alves CJ, Guimaraes Filho AA, Oliveira RM, Maksimov $P$, et al. Prevalence of anti-Toxoplasma gondii and antiNeospora caninum antibodies in swine from Northeastern Brazil. Rev Bras Parasitol Vet. 2010;19:80-4

40. Peters M, Wagner F, Schares G. Canine neosporosis: clinical and pathological findings and first isolation of Neospora caninum in Germany. Parasitol Res. 2000;86(1):1-7.

41. Reichel MP, Thornton RN, Morgan PL, Mills RJ, Schares G. Neosporosis in a pup. N Z Vet J. 1998;46(3):106-10

42. Heckeroth AR, Tenter AM. Immunoanalysis of three litters born to a Doberman bitch infected with Neospora caninum. Parasitol Res. 2007;100: 837-46.

43. Dubey JP, Koestner A, Piper RC. Repeated transplacental transmission of $N$. caninum in dogs. J Am Vet Med Assoc. 1990;197:857-60.

44. Björkman C, Sager H, Schares G. Serology. In: Ortega-Mora LM, et al. editors. Protozoal abortion in farm ruminants. Guidelines for diagnosis and control. Wallingford: CAB International:2007. p. 63-75.

45. Peters $M$, Lütkefels $E$, Heckeroth AR, Schares G. Immunohistochemical and ultrastructural evidence for Neospora caninum tissue cysts in skeletal muscles of naturally infected dogs and cattle. Int J Parasitol. 2001;31(10): 1144-8.

46. Schares G, Pantchev N, Barutzki D, Heydorn AO, Bauer C, Conraths FJ. Oocysts of Neospora caninum, Hammondia heydorni, Toxoplasma gondii and Hammondia hammondi in faeces collected from dogs in Germany. Int J Parasitol. 2005;35(14):1525-37.

47. Staub M. Investigation on the prevalence and epidemiology of Neospora infections in dogs in Rhineland-Palatinate, district Mayen-Koblenz (Germany). University, Hannover, Germany: Vet Med Diss; 2004. (in German)

48. Dubey JP, Lindsay DS. Transplacental Neospora caninum infection in dogs. Am J Vet Res. 1989;50(9):1578-9.

49. Dubey JP, Knickman E, Greene CE. Neonatal Neospora caninum infections in dogs. Acta Parasitol. 2005;50:176-9.

50. Dubey JP, Hemphill A, Calero-Bernal R, Schares G. Neosporosis in animals. 1st ed. Boca Raton: Taylor \& Francis Inc; 2017.

51. Robbe D, Passarelli A, Gloria A, Di Cesare A, Capelli G, lorio R, et al. Neospora caninum seropositivity and reproductive risk factors in dogs. Exp Parasitol. 2016;164:31-5.

52. Ghalmi F, China B, Kaidi R, Losson B. First epidemiological study on exposure to Neospora caninum in different canine populations in the Algiers District (Algeria). Parasitol Int. 2009;58:444-50.

53. Kramer L, de Risio L, Tranquilo VM, Magnino S, Genchi C. Analysis of risk factors associated with seropositivity to Neospora caninum in dogs. Vet Rec. 2004;154:692-3.

54. Collantes-Fernández E, Gómez-Bautista M, Miró G, Álvarez-García G, PereiraBueno J, Frisuelos C, et al. Seroprevalence and risk factors associated with Neospora caninum infection in different dog populations in Spain. Vet Parasitol. 2008;152:148-51.

55. Dubey JP, Lindsay DS. A review of Neospora caninum and neosporosis. Vet Parasitol. 1996;67(1-2):1-59

56. Wouda W, Dijkstra T, Kramer AM, van Maanen C, Brinkhof JM. Seroepidemiological evidence for a relationship between Neospora caninum infections in dogs and cattle. Int J Parasitol. 1999:29(10):1677-82.

57. Schares G, Heydorn AO, Cüppers A, Conraths FJ, Mehlhorn H. Hammondia heydorni-like oocysts shed by a naturally infected dog and Neospora caninum NC-1 cannot be distinguished. Parasitol Res. 2001;87(10):808-16.

\section{Submit your next manuscript to BioMed Central and we will help you at every step:}

- We accept pre-submission inquiries

- Our selector tool helps you to find the most relevant journal

- We provide round the clock customer support

- Convenient online submission

- Thorough peer review

- Inclusion in PubMed and all major indexing services

- Maximum visibility for your research

Submit your manuscript at www.biomedcentral.com/submit 